delicate integument and general fragility of larvae.

There is an almost complete lack of data on microdistribution. Most plankton nets are designed to filter large volumes of water and are not always equipped with closing devices to limit the depth of sampling. There is indirect evidence that larvae make small scale horizontal and vertical migrations and are not completely dependent on convection currents. Concentrations of larvae may be found in certain areas which suggest some sort of positive aggregating mechanism (J. M. Miller, Hawaii Institute of Marine Biology). In experimental conditions anchovy larvae will aggregate on small food patches (J. Hunter and G. Thomas, Southwest Fisheries Center, La Jolla, California) and herring larvae will perform vertical migrations which seem to have no obvious immediate adaptive value except in exploiting current systems at different levels in the water (S. Seliverstov, Polar Research Institute, Murmansk). A reshaping of ideas on larval distribution may emerge from the symposium.

Substantial knowledge on tolerance to high temperature, low oxygen, $\mathrm{H}_{2} \mathrm{~S}$, heavy metals and other potentially deleterious factors in the environment has been accumulating in the past few years. These data are of value for assessing the losses due to entrainment in power station effluents (D. Hoss et al., Atlantic Estuarine Fisheries Center, Beaufort, North Carolina) and for assessing the possibilities of exploiting heated effluents to improve larval growth in aquaculture. The improvement in culture techniques in the past few years has been remarkable, especially due to work in the United Kingdom, France and the United States. New sources of small food organisms and improvements in technique mean that, given adequate finance, most fish species can be reared from the egg. The main remaining stumbling block is obtaining mature adult fish. Although some species with extended spawning periods, such as the anchovy, car be induced to mature by the use of suitable photoperiods and temperature regimes, in most species the control of the maturation process is not practised, although spawning in ripe adults can be induced by injection of gonadotropins. In the symposium, Pütter's theory was once again resuscitated by Dr J. Flüchter (Bayrische Landanstalt für Fisherei, Starnberg) and it must be admitted that the possible use of dissolved organic matter as larval food has still not been resolved. In aquaculture the use of hybrids and gynogenesis is gradually coming into vogue (C. E. Purdon, Fisheries Laboratory, Lowestoft) and the manipulation of genetic material and selective breeding are obviously destined to be profitable lines of research in the future.
GRASSLAND ECOLOGY

\section{Land Use in the Veld}

from our Plant Ecology Correspondent

IT is now widely accepted that much of the grassland and savannah of Africa is not climatic climax vegetation. The combined effects of regular firing and intensive cattle grazing have imposed upon these habitats a powerful constraint which has deflected the natural course of succession. It is a matter of speculation whether these areas could have developed naturally in this way, for example, as a result of fires from lightning strikes, in the absence of human influence.

Strang (Biol. Conserv., 5, $96 ; 1973$ ) now describes the results of "bushencroachment" which is currently causing problems on the high veld of Rhodesia. In this upland area the rainfall $(75-105 \mathrm{~cm})$ is adequate for the support of woodland and the region can be regarded as a transition zone between dry savannah to the south and forest to the north. The early European settlers of this region, however, found extensive grasslands which were maintained by frequent fires and high grazing pressures from domesticated cattle. Land use in the high veld has changed little since those days, for only about $15 \%$ of the area has proved suitable for arable agriculture. More recently, however, the intensity and frequency of fires have been reduced very considerably and this, when combined with overgrazing which is becoming increasingly common, may be the chief factor underlying the spread of scrub and woodland.

The encroachment of scrub reduces foliage production in the grasses, and is therefore detrimental to the cattle industry. Experimental clearance of this woodland has been shown to increase the carrying capacity of the veld from one beast per 8-12 ha to one beast per 3-4 ha. Strang evaluates the various methods available for scrub control and clearance and concludes that the reintroduction of intensive burning would not be an efficient means of attaining these ends. If burning takes place just once every 4 years then it effectively means that one-quarter of the grazing lands will be non-productive in any given year. The alternative methods of control, such as manual clearance or

\title{
Haemin Effect on Protein Synthesis is Non-specific
}

THE conclusion reached by Mathews et al. in their study of the specificity of the control of protein synthesis by haemin (see Nature New Biology next Wednesday, June 20) was foreshadowed by the results of an earlier study by Mathews in which he showed that haemin stimulates the translation of endogenous messenger RNA and EMC viral RNA, as well as globin RNA, in the ascites sub-cellular system.

The non-specific effect of haemin is even more dramatically demonstrated by this new work in which Mathews et al. used the rabbit reticulocyte lysate as a test system and ${ }^{35} \mathrm{~S}$-methionine to label the nascent protein.

Mathews et al. show that not only rabbit globin but also the chiefly larger and presumably haemin-free reticulocyte proteins synthesized in small amounts (about $10 \%$ relative to globin) in the endogenous system (lacking added mRNA) are stimulated by haemin. There is a gradient of stimulatory effect from low to high molecular weight proteins for which Mathews et al. propose the explanation that completion of existing polypeptide chains contributes significantly to the pool of nascent proteins analysed.

Messenger-directed synthesis of mouse globin, $\alpha$ and $\beta$ calf lens crystallin, and EMC viral proteins in this system are all stimulated markedly by haemin. It has been suggested that haemin prevents the action of one or two different inhibitors of protein synthesis which accumulate in the lysate during incubation. Furthermore, the Cam. bridge group have shown previously that both the inhibitors act by preventing the association of met-tRNA $A_{F}$ with the small ribosomal subunit before binding mRNA. In such a case it would not be surprising if the effect on translation of mRNA were non-specific. The experiments presented in Nature $\mathrm{New}$ Biology provide a good test of the suggested mechanism of action of the inhibitors, and the new results are fully consistent with this effect. Mathews et al. cite an article in the press in which they claim that the met-tRNA F $^{-40 S}$ ribosome complex is a true intermediate in the initiation of protein synthesis.

Mathews et al. have thus exploded the long-standing myth that haemin (which is incorporated into haemoglobin) has a specific regulatory effect on globin synthesis. Previous workers in this field failed to carry out the appropriate control experiments before propounding this theory. The question remains whether the haemin effect has any physiological significance because, as Mathews et al. point out, evidence has been adduced to show that protein synthesis in HeLa cells (unlike that in reticulocytes) is resistant to inhibition by iron chelating agents. They suggest that the haemin effect, even if it does not operate in vivo, may be a "paradigm" for the control of protein synthesis when a general mechanism of switching on or off is required by the cell. 